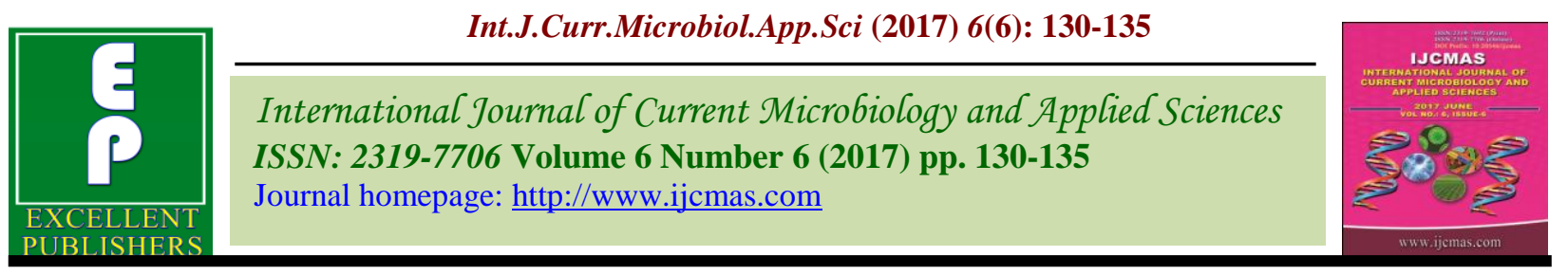

Original Research Article

https://doi.org/10.20546/ijcmas.2017.606.015

\title{
Effect of Irrigation Scheduling and Nitrogen Application on Yield, Grain Quality and Soil Microbial Activities in Direct-Seeded Rice
}

\section{Anita Kumawat, Seema Sepat, Dinesh Kumar*, Surender Singh, Dinesh Jinger, Shanti Devi Bamboriya and Anil Kumar Verma}

\author{
ICAR-Indian Agricultural Research Institute, New Delhi-110012, India \\ *Corresponding author
}

\begin{tabular}{|c|c|}
\hline & A B S T R A C T \\
\hline & \multirow{6}{*}{$\begin{array}{l}\text { A field experiment was carried out to study the response of irrigation scheduling } \\
\text { and split application of nitrogen on yield, grain quality parameters and soil } \\
\text { microbial activities of direct-seeded rice (DSR) during the kharif season } 2015 \text { at } \\
\text { New Delhi. The experiment was laid out in split plot design with } 12 \text { treatments } \\
\text { combination of irrigation scheduling viz., } 0 \mathrm{kPa} ; 10 \mathrm{kPa}, 20 \mathrm{kPa} \text { and } 40 \mathrm{kPa} \\
\text { irrigation scheduling threshold was maintained between tillering to flowering } \\
\text { stages in main plot and application of } \mathrm{N} @ 120 \mathrm{~kg} / \mathrm{ha} \text { as control (N0), half } \\
\text { recommended dose of nitrogen (RDN) as basal + one-fourth RDN at week } 2+ \\
\text { one-fourth RDN at week } 5 \text {, and one-fourth RDN as basal }+ \text { one-fourth RDN at } \\
\text { week } 2+\text { one-fourth RDN at week } 5+\text { one-fourth RDN at week } 9 \text { after sowing in } \\
\text { sub plot with three replications. The results bring to light that irrigation scheduling } \\
\text { at } 0 \mathrm{kPa} \text { recorded the highest yield, grain quality parameters and soil microbial } \\
\text { activities. As regards of N application the yield, grain quality parameters and soil } \\
\text { microbial activities were significantly influenced by split application of N. With } \\
\text { increase in the number of splits application along with basal application found } \\
\text { more effective over control. }\end{array}$} \\
\hline Keywords & \\
\hline $\begin{array}{l}\mathrm{Hu} \\
\mathrm{He} \\
\mathrm{Mi} \\
\mathrm{Pro} \\
\mathrm{So}\end{array}$ & \\
\hline Article Info & \\
\hline & \\
\hline & \\
\hline
\end{tabular}

\section{Introduction}

Rice (Oryza sativa L.) is the staple food for more than half of the world's population, and more than $90 \%$ of the world's rice is produced in Asia (FAO, 2009). However, the high water requirement of conventional, continuously flooded puddled transplanted rice (PTR) has become a major threat to the sustainability of rice production in regions facing current or future water scarcity. This is especially the case in the northwest IndoGangetic plains (IGP) of India, where the production of irrigated rice and wheat is critical for food security of the country (Humphreys et al., 2010). The steady decline of ground water has led to general acceptance of the need to find ways to reduce irrigation water input while maintaining yield (Yadav et $a l ., 2011)$. One way to reduce water input to rice is by improved irrigation management such as reduction in ponded water depth (Kukal and Aggarwal, 2002), use of saturated soil culture (Borrell et al., 1997) and directseeding of rice (Bhushan et al., 2007). Directseeded rice (DSR) is the technology which is 
water, labour and energy efficient along with eco-friendly characteristics and can be a potential alternative to conventional PTR (Kumar and Ladha, 2011). Here, sowing of rice is done under non-puddled conditions and the crop is not subjected to transplanting stress (Singh et al., 2008). Crop-weed competition, iron deficiency and nematodes are the major problems in DSR (Kreye et al., 2009). Nonetheless, the shifting from TPR to DSR technologies can save resources in long run. Likewise, the nitrogen use efficiency (NUE) in rice is very low $\sim 33 \%$ as applied $\mathrm{N}$ is lost through various processes. The different moisture conditions in DSR as compared to PTR lead to temporal variability of crop response to $\mathrm{N}$ (Cassman et al., 1996). Greater fertiliser NUE in rice can be achieved by using Nefficient varieties, improving timing and application methods and better incorporation of basal $\mathrm{N}$ fertiliser application without standing water (Ali et al., 2007). In the light of the above context the present study was undertaken to investigate the effect of water and nitrogen management practices to improve the yield, grain quality and soil microbial activities of DSR.

\section{Materials and Methods}

A field experiment was conducted during the kharif season 2015 at the research farm of ICAR-Indian Agricultural Research Institute, New Delhi, India. The farm was situated at latitude of $28^{\circ} 40^{\prime} \mathrm{N}$ and longitude of $77^{\circ} 12^{\prime}$ $\mathrm{E}$, altitude of $228.6 \mathrm{~m}$ above the mean sea level. The soil was sandy clay loam with low in organic $\mathrm{C}$ and available $\mathrm{N}$, medium in available $\mathrm{P}$ and high in available $\mathrm{K}$ with $\mathrm{pH}$ 7.9 at the experimental site. The total rainfall received during the period of experimentation was $748.5 \mathrm{~mm}$. The experiment was laid out in split plot design with 12 treatments combination of irrigation scheduling $(0 \mathrm{kPa}$; $10 \mathrm{kPa}, 20 \mathrm{kPa}$ and $40 \mathrm{kPa}$ irrigation scheduling threshold was maintained between tillering to flowering stages) in main plot and
N application@120 kg/ha (control (N0), half RDN basal + one-fourth at week 2 + onefourth at week 5 and one-fourth RDN basal + one-fourth at week $2+$ one-fourth at week $5+$ one fourth at 9 week after sowing) in sub plot with three replications. The rice variety 'Pusa Basmati 1509' was sown with the help of multi-row crop planter at $22.5 \mathrm{~cm}$ row to row spacing on June 24,2015 . The seed rate was $30 \mathrm{~kg} / \mathrm{ha}$. The recommended dose of $60 \mathrm{~kg}$ P2O5 through single super phosphate and 60 $\mathrm{kg} \mathrm{K} 2 \mathrm{O} / \mathrm{ha}$ through Muriate of potash was applied basal. A pre-emergence application of pendimethalin@ $0.75 \mathrm{~kg} /$ ha followed by post emergence application of bispyribac @ 0.025 $\mathrm{kg} / \mathrm{ha}$ was done for effective weed management. Irrigations were given as per irrigation scheduling in different plots during the crop season. Data on yield, grain quality parameters and soil microbial activities were analysed as per the standard procedures. The grain yield was calibrated after the produce was sun dried for three days. The weighing for yield was done when the moisture content in grain was $12.5 \%$. The physical characters of grain were recorded using standard procedures as per the details given below:

$$
\begin{aligned}
& \text { Hulling }(\%)=\frac{\text { Weight of brown rice }(\mathrm{g})}{\text { Weight of rough rice }(\mathrm{g})} \times 100 \\
& \text { Milling }(\%)=\frac{\text { Weight of milled rice }(\mathrm{g})}{\text { Weight of rough rice }(\mathrm{g})} \times 100
\end{aligned}
$$

Weight of whole milled rice $(\mathrm{g})$

Head rice recovery $(\%)=$ $\times 100$

$$
\text { Weight of rough rice }(\mathrm{g})
$$

\section{Results and Discussion}

\section{Yield and grain quality}

The outcomes of the study showed that scheduling of irrigation at various thresholds 
and split application of $\mathrm{N}$ significantly influenced the yield, rice grain quality parameters (Table 1) and microbial activities (Table 2) of DSR. The highest yield was observed with irrigation scheduling at $0 \mathrm{kPa}$ i.e. in saturated condition which was found at par with maintaining water threshold in soil through irrigation at $10 \mathrm{kPa}$. Thereafter irrigation scheduling at higher threshold i.e. $20 \mathrm{kPa}$ and $10 \mathrm{kPa}$ throughout the growing season except $40 \mathrm{kPa}$ during tillering to flowering recorded a decline in grain yield of DSR during the growing season. Though, the treatments $10 \mathrm{kPa}$ throughout the growing season except $40 \mathrm{kPa}$ during tillering to flowering was found comparable with $20 \mathrm{KPa}$ during the experimentation season. The similar findings also reported by Mahajan et al., (2006) and Maheswari et al., (2007). Regarding $\mathrm{N}$ application, the yield was significantly improved by increasing number of splits of $\mathrm{N}$ fertilizer over control. The lowest values of yield were recorded in control (N0) plots which were significantly lower than the $\mathrm{N}$ application treatments. The highest yield was observed with split application of RDN as one-fourth basal + onefourth at week $2+$ one-fourth at week $5+$ one fourth at week 9 after sowing was found comparable with one-fourth RDN basal + one-fourth at week $2+$ one-fourth at week 5 . The variation in partitioning of photo synthates in grain and vegetative organs of different treatments possibly caused a significant variation in yield (Jat et al., 2014). The significant differences were recorded in the quality parameters of rice grain along with different irrigation scheduling thresholds and nitrogen. The highest value was observed with irrigation scheduling at $0 \mathrm{kPa}$ which was found at par with $10 \mathrm{kPa}$ in terms of quality parameters such as hulling, milling, head rice recovery, protein content and protein yield in DSR.

Table.1 Effect of irrigation scheduling and $\mathrm{N}$ application on yield and Rice grain quality parameters of direct seeded rice

\begin{tabular}{|c|c|c|c|c|c|c|}
\hline Treatment & $\begin{array}{l}\text { Grain } \\
\text { yield } \\
\text { (t/ha) }\end{array}$ & $\begin{array}{l}\text { Hulling } \\
(\%)\end{array}$ & $\begin{array}{c}\text { Milling } \\
(\%)\end{array}$ & $\begin{array}{c}\text { Head rice } \\
\text { recovery }(\%)\end{array}$ & $\begin{array}{c}\text { Protein } \\
\text { content } \\
(\%)\end{array}$ & $\begin{array}{l}\text { Protein yield } \\
(\mathrm{kg} / \mathrm{ha})\end{array}$ \\
\hline \multicolumn{7}{|c|}{ Irrigation scheduling } \\
\hline $0 \mathrm{kPa}$ & 4.83 & 70.3 & 64.7 & 54.7 & 7.72 & 376.9 \\
\hline $10 \mathrm{kPa}$ & 4.68 & 68.0 & 63.7 & 52.7 & 7.64 & 361.6 \\
\hline $20 \mathrm{kPa}$ & 4.24 & 67.3 & 63.3 & 50.7 & 7.50 & 324.2 \\
\hline $40 \mathrm{kPa}^{*}$ & 3.96 & 67.0 & 62.0 & 48.8 & 7.24 & 291.9 \\
\hline $\mathrm{SEm} \pm$ & 0.13 & 0.61 & 0.67 & 0.75 & 0.10 & 11.71 \\
\hline $\operatorname{LSD}(P=0.05)$ & 0.46 & 2.11 & NS & 2.58 & NS & 40.51 \\
\hline \multicolumn{7}{|l|}{ Nitrogen application } \\
\hline Control $\left(\mathrm{N}_{0}\right)$ & 3.60 & 65.0 & 61.3 & 48.7 & 6.70 & 229.3 \\
\hline $\mathrm{N}_{1}{ }^{* *}$ & 4.62 & 67.7 & 63.0 & 50.7 & 7.76 & 359.6 \\
\hline $\mathrm{N}_{2}{ }^{* * *}$ & 5.06 & 71.7 & 66.0 & 55.8 & 8.12 & 427.0 \\
\hline $\mathrm{SEm} \pm$ & 0.06 & 0.53 & 0.50 & 0.40 & 0.07 & 8.35 \\
\hline $\operatorname{LSD}(P=0.05)$ & 0.18 & 1.58 & 1.50 & 1.21 & 0.20 & 25.04 \\
\hline
\end{tabular}

$* 10 \mathrm{kPa}$ throughout the growing season except $40 \mathrm{kPa}$ during tillering to flowering;

$* *$ Half basal + one-fourth at week $2+$ one-fourth at week 5

*** One-fourth basal + one-fourth at week $2+$ one-fourth at week $5+$ one-fourth at week 9 
Table.2 Effect of irrigation scheduling and nitrogen application on soil Microbial activities in direct seeded rice

\begin{tabular}{lcccc}
\hline Treatment & $\begin{array}{c}\text { Dehydrogenase } \\
\text { activity } \\
(\mu \mathrm{g} \text { TPF/g soil/day) }\end{array}$ & $\begin{array}{c}\text { Alkaline Phosphatase } \\
\text { activity } \\
(\mu \mathrm{g} / \mathrm{g} \text { soil/hr) }\end{array}$ & $\begin{array}{c}\text { Microbial biomass } \\
\text { carbon( } \mu \mathrm{g} / \mathrm{g} \text { soil })\end{array}$ & $\begin{array}{c}\text { Fluorescein } \\
\text { diacetate activity } \\
(\mu \mathrm{g} / \mathrm{g} \text { soil/hr })\end{array}$ \\
\hline $\begin{array}{l}\text { Irrigation scheduling } \\
0 \mathrm{kPa}\end{array}$ & 138.5 & 36.6 & & 1.21 \\
$10 \mathrm{kPa}$ & 141.4 & 34.0 & 143.4 & 1.18 \\
$20 \mathrm{kPa}$ & 158.2 & 32.6 & 138.9 & 1.01 \\
$40 \mathrm{kPa}$ & 161.1 & 31.6 & 127.7 & 0.94 \\
$\mathrm{SEm} \pm$ & 1.02 & 4.22 & 0.02 \\
$\mathrm{LSD}(P=0.05)$ & 1.45 & $\mathrm{NS}$ & 14.60 & 0.08 \\
Nitrogen application & 5.02 & 26.0 & 105.6 & 0.88 \\
$\mathrm{Control}\left(\mathrm{N}_{0}\right)$ & 124.1 & 34.3 & 134.0 & 1.14 \\
$\mathrm{~N}_{1}{ }^{* *}$ & 138.8 & 40.7 & 153.1 & 1.24 \\
$\mathrm{~N}_{2}{ }^{* * *}$ & 186.5 & 0.92 & 2.86 & 0.01 \\
$\mathrm{SEm} \pm$ & 0.97 & 2.75 & 8.59 & 0.03 \\
LSD $(P=0.05)$ & 2.92 & & & \\
\hline
\end{tabular}

$* 10 \mathrm{kPa}$ throughout the growing season except $40 \mathrm{kPa}$ during tillering to flowering;

$* *$ Half basal + one-fourth at week $2+$ one-fourth at week 5

*** One-fourth basal + one-fourth at week $2+$ one-fourth at week $5+$ one-fourth at week 9

Likewise, $\mathrm{N}$ management also significantly influenced the value of hulling, milling, head rice recovery, protein content and protein yield. Application of one-fourth RDN basal + one-fourth at week $2+$ one-fourth at 5 week + one fourth at week 9 after sowing recorded highest values followed by $\mathrm{N}$ application as one-fourth RDN basal + one-fourth at week 2 + one-fourth at week 5 . The higher values of grain quality parameters with irrigation scheduling and $\mathrm{N}$ fertilization might be due to increase in $\mathrm{N}$ concentrations in rice grain and this attributed to increase in protein content which gave less breakage (Singh et al., 2015). Therefore, higher protein content imparts strength to the grains resulted in greater head rice recovery (Kaushal et al., 2010).

\section{Soil microbial activities}

Soil microbial activities viz. dehydrogenase activity, microbial biomass carbon (MBC) and fluorescein diacetate activity (FDA) were significantly influenced by different irrigation scheduling thresholds at flowering stage except alkaline phosphatase activity (APA). The maximum soil dehydrogenase activity was recorded in the treatments with irrigation scheduling at $10 \mathrm{kPa}$ throughout the growing season except $40 \mathrm{kPa}$ during tillering to flowering which was at par with $20 \mathrm{KPa}$. The higher dehydrogenase activity might be owing to availability of aerobic environment with higher levels of irrigation threshold (Saha, 2013). However, the maximum activity of APA, MBC and FDA was observed with 0 $\mathrm{kPa}$ irrigation scheduling threshold which was statistically at par with $10 \mathrm{kPa}$. This could be due to optimum moisture availability which gave a favourable environment for soil habituating microbes (Jedidi et al., 2004). The significant effect of split application of $\mathrm{N}$ was recorded on soil microbial activities over control. The soil microbial activities were higher with split application of one-fourth RDN basal + one-fourth at week 2 + onefourth at week $5+$ one fourth at week 9 after sowing recorded highest values followed by $\mathrm{N}$ application as one-fourth RDN basal + onefourth at week $2+$ one-fourth at week 5 . The 
microbial parameters indicated the biological redox system respiratory chain enzyme of soil microorganisms, which denoted that microbial activities were influenced with $\mathrm{N}$ application. The MBC is component of soil organic matter and it plays a vital role in nutrient cycling and stabilization of soil organic matter (Dhull et al., 2004).

In conclusion, the study concludes that irrigation scheduling at $0 \mathrm{kPa}$ i.e. in saturated condition recorded the highest productivity, grain quality parameters such as hulling, milling, head rice recovery, protein content and protein yield, and the soil microbial activities which were found on par with maintaining water threshold in soil through irrigation at $10 \mathrm{kPa}$. Likewise, the highest yield, grain quality parameters and soil microbial activities were observed with split application of RDN as one-fourth basal + onefourth at week $2+$ one-fourth at week $5+$ one fourth at week 9 after sowing was found comparable with one-fourth RDN basal + one-fourth at week $2+$ one-fourth at week 5 .

\section{References}

Ali, M.A., Ladha, J.K., Rickman, J. and Lales, J.S. 2007. Nitrogen dynamics in lowland rice as affected by crop establishment and nitrogen management. Journal of Crop Production 20: 89-105.

Bhushan, L., Ladha, J.K., Gupta, R.K., Singh, S., Tirol-Padre, A., Saharawat, Y.S., Gathala, M. and Pathak, H. 2007. Saving of water and labour in a ricewheat system withno-tillage and direct seeding technologies. Agronomy Journal 99: 1288-1296.

Borrell, A., Garside, A. and Fukai, S. 1997. Improving efficiency of water use for irrigatedrice in a semi-arid tropical environment. Field Crops Research 52: 231-248.
Cassman, K.G., Gines, H.C., Dizon, M., Samson, M.I. and Alcantara, J.M. 1996. Nitrogen-use efficiency in tropical lowland rice systems: Contributions from indigenous and applied nitrogen. Field Crop Research 47: 1-12.

Dhull, S.K., Goyal, S., Krishan, K.K. and Mool, C.M. 2004. Microbial biomass carbon and microbial activities of soils receiving chemical fertilizers and organic amendments. Archives of Agronomy and Soil Science 50: 641647.

FAO, 2009. How to feed the world in 2050. Humphreys, E., Kukal, S.S., Christen, E.W., Singh, B., Yadav, S. and Sharma, R.K. 2010. Halting the ground water decline in North West India-which crop technologies will be winners? Advances in Agronomy 109: 155-217

Jadhav, A.S., Dhoble, M.V. and Chavan, D.A. 2003. Effect of irrigation and nitrogen on yield and quality of Basmati rice. Journal of Maharashtra Agricultural Universities 28(2): 187-188

Jat, S.L., Shivay, Y.S. and Parihar, C.M. 2014. Effect of dual-purpose summer legumes and zinc fertilization on system productivity, economics and nutrient use-efficiencies of rice (Oryza sativa) wheat (Triticum aestivum) cropping system. Indian Journal of Agricultural Sciences 84(8): 942-950.

Jedidi, N., Hassen, A., Van Cleemput, O. and Hiri, A. 2004. Microbial biomass in a soil amended with different types of organic wastes. Waste Management Research 22: 93-99.

Kaushal, A.K., Rana, N.S., Singh, A. and Srivastav, A. 2010. Response of levels and split application of nitrogen in green manured wetland rice (Oryza sativa L.). Asian Journal of Agricultural Sciences 2(2): 42-46.

Kreye, C., Bouman, B.A.M., Castaneda, A.R., Lampayan, R.M., Faronilo, J.E., 
Lactaoen, A.T. and Fernandez, L. 2009. Possible causes of yield failure in tropical aerobic rice. Field Crops Research 111: 197-206.

Kukal, S.S., Aggarwal, G.C. 2002. Percolation losses of water in relation to puddlingintensity and depth in a sandy loam rice (Oryza sativa L.) field. Agric. Water Manage. 57: 49-59.

Kumar, V. and Ladha, J.K. 2011. Direct Seeding of Rice: Recent Developments and Future Research Needs. Advances in Agronomy 111: 297.

Mahajan, G., Sardana, V., Brar, A.S. and Gill, M.S. 2006. Effect of seed rates, irrigation intervals and weed pressure on productivity of rice (Oryza sativa L.). Indian Journal of Agricultural Sciences 76: $756-759$.

Maheswari, J., Maragatham, N. and Martin, G.J. 2007. Relatively simple irrigation scheduling and $\mathrm{N}$ application enhances the productivity of aerobic rice (Oryza sativa L.). American Journal of Plant Physiology 2: 261- 68.

Saha, S. 2013. Effect of nitrogen nutrition and production techniques of rice (Oryza sativa $\mathrm{L}$.) on productivity, soil chemical and microbial properties, M.Sc. thesis submitted to IARI New Delhi.

Singh, D.K., Pandey, P.C., Priyanker, Q.A. and Gupta, S. 2015. Nitrogen management strategies for direct seeded aerobic rice (Oryza sativa L.) grown in mollisols of Uttarakhand (India). International Journal of Applied and Pure Science in Agriculture 1(7): 23945532.

Singh, Y., Singh, V.P., Chauhan, B., Orr, A., Mortimer, A.M., Johnson, D.E. and Hardy, B. 2008. Direct seeding of rice and weed management in the irrigated rice-wheat cropping system of the IndoGangetic Plains. Los Baños (Philippines): International Rice Research Institute, and Pantnagar (India): Directorate of Experiment Station, G.B. Pant University of Agriculture and Technology, pp. 272.

Yadav, S., Gill, G., Humphreys, E., Kukal, S.S. and Walia, U.S. 2011. Effect of water management on dry direct seeded rice and puddled transplanted rice Part 1: Crop performance. Field Crops Research 120: 112-122.

\section{How to cite this article:}

Anita Kumawat, Seema Sepat, Dinesh Kumr, Surender Singh, Dinesh Jinger, Shanti Devi Bamboriya and Anil Kumar Verma. 2017. Effect of Irrigation Scheduling and Nitrogen Application on Yield, Grain Quality and Soil Microbial Activities in Direct-Seeded Rice. Int.J.Curr.Microbiol.App.Sci. 6(6): 130-135. doi: https://doi.org/10.20546/ijcmas.2017.606.015 